\title{
Local and Time Changes over a 66-Year Period and Annual Relocation of Saudi Arabian Subtropical High Pressure
}

\author{
Hasan Lashkari*, Ali Akbar Matkan, Zainab Mohammadi \\ Department of Geography, Shahid Beheshti University, Tehran, Iran \\ Email: ^Dr_lashkari61@yahoo.com, a-matkan@sbu.ac.ir, Mohamadi.1040@yahoo.com
}

How to cite this paper: Lashkari, H., Matkan, A.A. and Mohammadi, Z. (2016) Local and Time Changes over a 66-Year Period and Annual Relocation of Saudi Arabian Subtropical High Pressure. Open Journal of Geol$o g y, 6,1080-1095$.

http://dx.doi.org/10.4236/ojg.2016.69081

Received: May 10, 2016

Accepted: September 11, 2016

Published: September 14, 2016

Copyright $\odot 2016$ by authors and Scientific Research Publishing Inc. This work is licensed under the Creative Commons Attribution International License (CC BY 4.0).

http://creativecommons.org/licenses/by/4.0/

\begin{abstract}
Saudi Arabian subtropical high pressure is a major system affecting general circulation of the atmosphere of west Asia. Its annual relocation affects the relocation of other systems in the area, such as Mediterranean cyclones, Sudanese low pressure areas, and west wind waves. This system is known to relocate to the south and north in response to outward solar relocation, but the reasons behind its eastern and western relocation have not been studied thoroughly. The present study examined 1000 and $850 \mathrm{HPa}$ levels over the course of 66 years (1948-2015) to determine a pattern of latitudinal and longitudinal relocation of the system using synoptic maps. The research showed that, after 2008, high pressure latitudinal and longitudinal swings were larger than in previous years and the annual high pressure relocation was not in concord with the apparent motion of the sun. At the onset of autumnal moderation, the high pressure core was positioned to the north of Saudi Arabia $\left(22^{\circ}-30^{\circ}\right.$ north latitude and $42^{\circ}-50^{\circ}$ south longitude). Southern movement continued until the end of March, when the core again relocated to the north. These relocations first occurred slowly, but the northern relocation occurred very quickly from May to June, such that the core moved northward $22^{\circ}$ to $30^{\circ}$. After June, the core did not relocate much until the end of September. After September, it relocated strongly south in all time periods. It was noted that high pressure over Saudi Arabia had two cores from June to September in some years; in others the high pressure core was in southwestern Iran and Iraq. In still others, a southwest to northeast high pressure tab entered Iran from the southwest (Khuzestan) and continued northward with a core forming in the northern Caspian Sea.
\end{abstract}

\section{Keywords}

Analysis, Time and Local Change, Subtropical High Pressure, Saudi Arabia 


\section{Introduction}

In the recent past and according to recent studies, subtropical high pressure, especially that over Saudi Arabia, is considered to be a factor that intensifies drought, dryness, and stability of the weather of Iran. Climatological and meteorological events, especially synoptic events, are relative. For example, a system with $1050 \mathrm{HPa}$ of central pressure could be a low pressure system on a map at a specific time and place or a high pressure system when compared to adjacent areas at another time and place. Although the dynamic mechanisms of an anticyclone or a cyclone are stable over a short period of time, its performance will differ under different geographical and topographical circumstances.

Like all anticyclones, the dominant mechanism in the subtropical high pressure of Saudi Arabia is the same dynamically. The dominant mechanisms in an anticyclone are subsidence, stability, great thickness, tangible heat, and high potential, but the anticyclone of Saudi Arabia performs differently on different occasions. When the Saudi Arabian anticyclone turns toward the east under specific circumstances and resides over the warm Arabian Sea, Sea of Oman, and the Indian Ocean, it operates very differently from the time it turns west and resides over the Arabian Peninsula and the Red Sea. Iran falls into a dry climate belt and features a dry and semiarid climate in response to its geographical location and topography and relative position in the general movement of the atmosphere. Because of its geographical location, the greater part of Iran lies in the path of subtropical high pressure swings ( $23^{\circ}$ to $40^{\circ}$ east latitude). Saudi Arabian high pressure forms as a major subtropical high pressure cell on the Arabian Peninsula and moves upward and downward in latitude according to the apparent motion of the sun. This cell is dominant in Iran during the hot period of the year; its long term persistence causes hot and dry summers. In the hot period of the year, this cell moves toward the upper latitudes and resides in northern Saudi Arabia, the Persian Gulf, and occasionally in southern Iran and eliminates the instability in the region [1]. Research shows that there is an obvious difference in the establishment of the center of subtropical high pressure in the lower, middle and upper levels of the troposphere. The subtropical high pressure over the Azores in the northeastern Atlantic Ocean is in the lower level; the high pressure in northwest Africa and Saudi Arabia is in the middle level; the high pressure of Tibet is in the upper level of the troposphere; these are independent centers. The center of high pressure in Iran lies in both the middle and upper levels [2].

Galton coined the word anticyclone in 1861 for pressure centers with different cyclonic features [3]. He states that subtropical high pressure lies in a belt at $30^{\circ}$ north latitude in the upper troposphere and is considered to be a Hedley heat cell [4]. Gurtjohn believes that subtropical high pressure lies in a transitive zone between the tropical areas (convection formation place) and middle latitudes (frontal cyclone dominance) and states that subtropical high pressure has a strong effect on the adjacent regions [5]. These high pressure are dynamically hot at all levels. As the elevation increases, the axis of high pressure slants to the southwest coincident with the warmer weather in the upper troposphere caused by air subsidence in the upper levels as discussed by Berry and 
Carlton [6].

Hejazizadeh studied the synoptic effects of subtropical high pressure in Iran on subtropical high pressure swings during seasonal changes. She believed that as the pressure center of the polar cell decreases in elevation, the difference in energy increases between the polar cap and the southern bound, which intensifies the slopes of lines at the same elevation and the western currents in the upper latitudes. The center of the cold weather at the polar cap will be pushed to the southern latitudes, which pushes back the subtropical high pressure and causes rainfall in Iran. She has described the 584 decameter geopotential contour as the northern border of the subtropical high pressure [7]. Sadeghinia studied local changes in summer rainfall in southern Iran using subtropical high pressure in the Azores. He chose six pervasive rainfall patterns and he recognized two general patterns. In the first pattern, the rotary movement of the seasonal system transports humidity from the Indian Ocean and adjacent seas to the lower levels of the troposphere. The TAB center of subtropical high pressure will be western-eastern in response to the western hod spreading in the middle levels toward western Iran. For this rainfall pattern, a maximum reduction in altitude occurs at 300 and $500 \mathrm{HPa}$ because of subtropical system debilitation in the lower levels of the troposphere and because the thickness of the convection layer reaches $500 \mathrm{HPa}$. In the second pattern, the seasonal system spreads to the south and, when seasonal cyclones approach, heavy rainfall occurs. In this condition, penetration of the seasonal weather to $700 \mathrm{HPa}$ transports the subtropical high pressure to a higher level and results in convection rainfall. In this pattern, the maximum reduction in geopotential height occurs at 700 $\mathrm{HPa}$ and the thickness of the convection layer rises above $700 \mathrm{HPa}$ [8].

Lashkari studied in the patterns of intense rainfall in southwestern Iran by examining 50 systems that caused flooding. He believed that the rainfall was caused by Sudanese low pressure and the Red Sea convergence area and identified four patterns in which the Sudanese system led to rainfall that caused flooding in southwest Iran. He carried out synoptic analysis of sample flood systems in western and southwestern Iran and found that the characteristics of western Iran caused both severe drought and heavy rainfall leading to flooding. The system's synoptic and thermodynamic features produced intense instability, heavy rainfall, and rainfall in the cold period of the year. There was high potential for storms from 20 to 24 January in the south and southwest that was reinforced by the Sudanese low pressure [9]. Kianipour studied El Niño and anomalies in western and southwestern rainfall and believed that El Niño caused the reduction in rainfall in southwestern Iran. He showed that the position of the Saudi Arabian subtropical high pressure cells at 300, 500 and $700 \mathrm{Hpa}$ in the cold period of the year over the Red Sea, Sea of Oman, and the Indian Ocean caused longitudinal oscillation. This oscillation ranged from the Horn of Africa to the Persian Gulf. He also indicated the position of the Saudi Arabian high pressure zone [10].

Khosh-Akhlaghetal studied winter drought and wet synoptic systems in southwestern Iran and concluded that movement of the subtropical high pressure belt played an important role winter rainfall oscillations in southwestern Iran. These produced 
drought, accompanied by movement southward. It location over the peninsula and an increase in geopotential height during these periods are accompanied by movement eastward and settlement of a high pressure system over the Arabian Sea and a decrease in geopotential height. Khoshakhlagh (1977-1998) studied pervasive droughts in Iran using synoptic analysis and compared them with wet periods. He recognized movement of the Azores high pressure belt, Siberian high pressure, and subtropical high pressure meridian to be causes of the droughts and wet periods in Iran [10].

Lashkari and Mohammadi studied the effect of the Saudi Arabian subtropical high pressure on rainfall systems in southern and southwestern Iran. They showed that in all rainfall systems, the orbital components of the wind over the Arab Sea and eastern Sea of Oman and their meridian components spread heat and humidity from these seas to the Sudanese low pressure. The maximum humidity occurred over Ethiopia and the southern Red Sea; this was transported to Iran by the southern currents of the low pressure hod at sea level and the air currents at the front of the hod at higher levels [11]. National studies in this field include [12]-[17].

\section{Materials and Methods}

The range of the study was first chosen. The probable movement of high pressure over a 1-year time span at $20^{\circ}$ to $80^{\circ}$ east longitude and $0^{\circ}$ to $60^{\circ}$ north latitude was chosen. Topographical maps for 700,850 , and $1000 \mathrm{HPa}$ at 5 curved geopotential meter distances were taken from the NCEP website (www.ncep.noaa.gov). Image (1) shows examples of topographical maps and the range studied. The average map for each month in a 66-year time span was extracted. Next, 2376 maps for the three levels were downloaded from the NOAA website (www.esrl.noaa.gov) Figure 1.

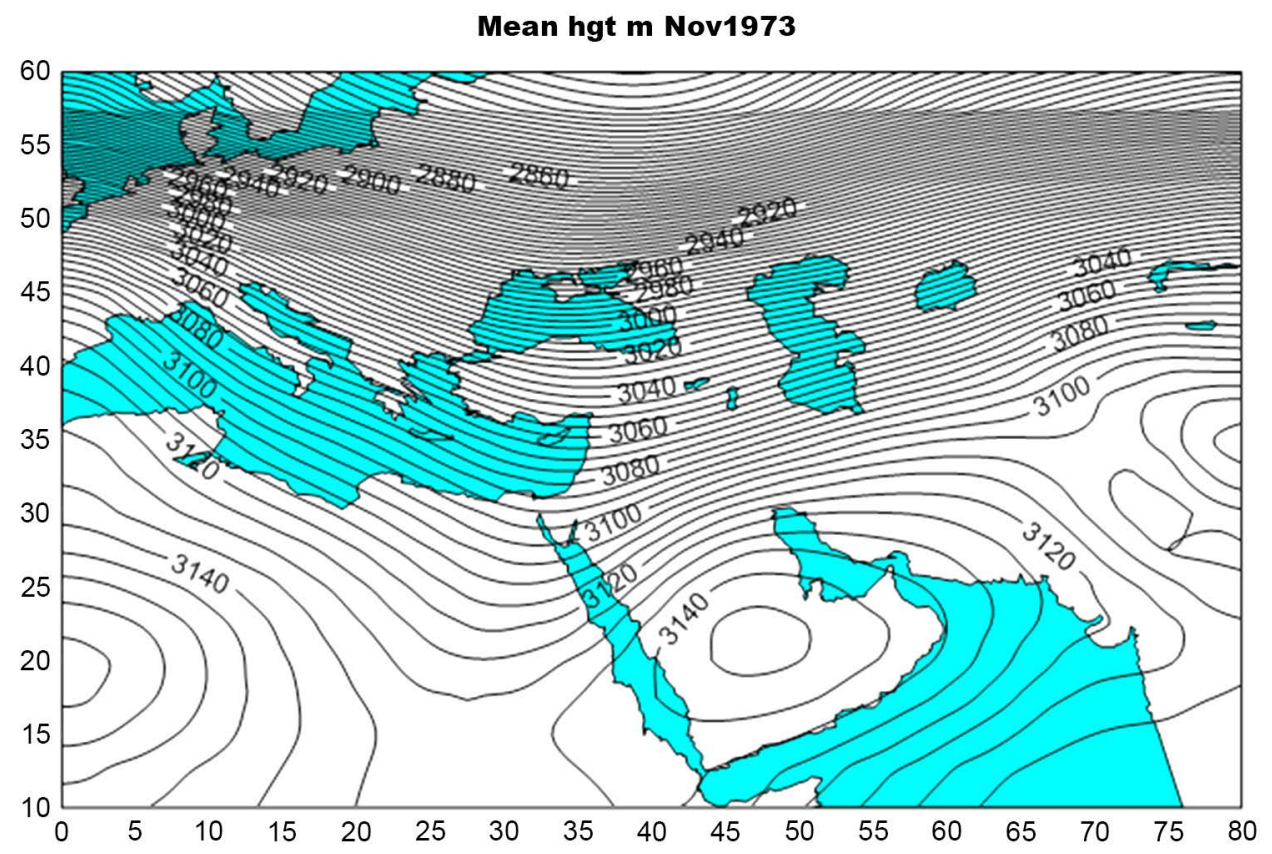

Figure 1. Topographical maps of study area and range studied. 
Next, the central core of each Saudi Arabian high pressure was delineated on the map. The latitude and longitude of the cores were entered into Excel and this Excel file was used in ARC GIS to transform the cores into raw maps.

As shown, the transformed points on the maps show the longitudinal and latitudinal ranges. In Figure 2, the expansion of the central core for each month of the year for a 10-year time span was designated using the latitudinal and longitudinal points to transform the maps.

In Table 1, the density of the centers were identified using geographical longitude and latitude for each month of the year. Local changes in high pressure were analyzed using the longitude and latitude values over the 1-year time span. Time changes for the

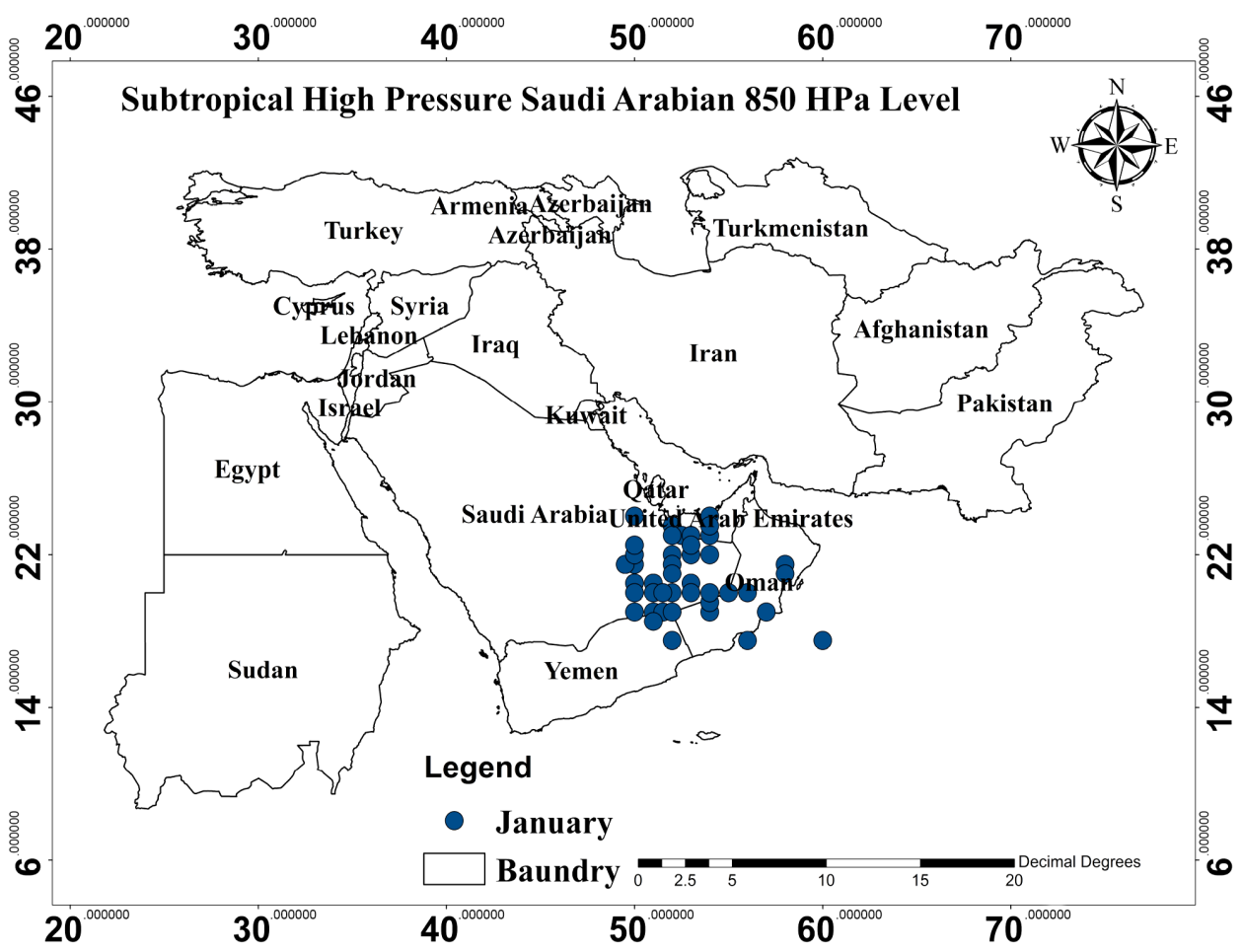

Figure 2. Designation of central cores on ARC GIS map.

Table 1. Designation of longitudinal and latitudinal points.

\begin{tabular}{ccccccc}
\hline & LON APR & LAT APR & LON MAY & LAT MAY & LON JUN & LAT JUN \\
\hline $1948-58$ & 53 & 22 & 47 & 23 & 56 & 46 \\
$1958-68$ & 54 & 22 & 50 & 22 & 55 & 41 \\
$1968-78$ & 55 & 20 & 46 & 19 & 56 & 43 \\
$1978-88$ & 57 & 20 & 48 & 22 & 57 & 41 \\
$1988-98$ & 56 & 20 & 47 & 23 & 60 & 49 \\
$1998-2008$ & 57 & 21 & 47 & 23 & 52 & 44 \\
$2008-2014$ & 58 & 19 & 46 & 23 & 52 & 43 \\
\hline
\end{tabular}


high pressure was analyzed using the longitude and latitude for each month of the year. Analysis of all maps and tables for all three levels was time-consuming and voluminous; thus, the 800 and $1000 \mathrm{HPa}$ levels were excluded from this essay. The reason for this exclusion was the incoherence of the cores at these levels compared to the other two levels. In some years, no closed centers occurred at the $1000 \mathrm{HPa}$ level, or the long time span for closed centers made identifying the exact characteristics of the center impossible.

\section{Findings}

\subsection{Analyzing Local Changes of Saudi Arabian High Pressure}

Table 2 shows the range of latitude and changes in the Saudi Arabian central core for different months of the year at the $850 \mathrm{HPa}$ level for the ten year time span.

\subsubsection{Autumn}

The first row of Table 3 shows the expansion of the central cores of the high pressure for the 10-year time span. Shows changes over the three months of autumn for the 10 -year time span. Diagram 1 for the first ten years (1948-58), subtropical high pressure centers expanded from $24^{\circ}$ to $30^{\circ}$ north latitude. Their minimum latitudinal expansion in the following years oscillated between $22^{\circ}$ and $24^{\circ}$, but the maximum range of expansion in the next three decades was to $27^{\circ}$ north and then increased $2^{\circ}$ to $3^{\circ}$ to $29^{\circ}-30^{\circ}$ north latitude.

In November of nearly all decades, the southern limit of expansion decreased $2^{\circ}$ to $20^{\circ}$ north latitude. The upper limit of expansion decreased $2^{\circ}$ to $25^{\circ}$ north. Over three

Table 2. Range of latitude and changes in Saudi Arabian central core in different months at $850 \mathrm{HPa}$.

\begin{tabular}{|c|c|c|c|c|c|c|c|c|c|c|c|c|c|c|}
\hline \multirow{2}{*}{ Latitude } & \multicolumn{2}{|c|}{$1948-58$} & \multicolumn{2}{|c|}{$1958-68$} & \multicolumn{2}{|c|}{$1968-78$} & \multicolumn{2}{|c|}{$1978-88$} & \multicolumn{2}{|c|}{$1988-98$} & \multicolumn{2}{|c|}{$1998-2008$} & \multicolumn{2}{|c|}{$2008-2014$} \\
\hline & $\min$ & $\max$ & $\min$ & $\max$ & $\min$ & $\max$ & $\min$ & $\max$ & $\min$ & $\max$ & $\min$ & $\max$ & $\min$ & $\max$ \\
\hline February & 20 & 27 & 15 & 25 & 18 & 25 & 18 & 24 & 17 & 24 & 17 & 23 & 17 & 23 \\
\hline March & 17 & 25 & 8 & 15 & 15 & 25 & 15 & 25 & 15 & 23 & 18 & 23 & 20 & 25 \\
\hline May & 19 & 24 & 21 & 24 & 19 & 23 & 19 & 24 & 19 & 24 & 20 & 24 & 19 & 23 \\
\hline June & 43 & 51 & 38 & 45 & 41 & 45 & 34 & 45 & 43 & 51 & 44 & 47 & 42 & 48 \\
\hline July & 44 & 47 & 39 & 40 & 40 & 50 & 39 & 47 & 36 & 49 & 43 & 52 & 43 & 49 \\
\hline October & 24 & 30 & 22 & 27 & 24 & 27 & 22 & 27 & 24 & 29 & 24 & 30 & 25 & 29 \\
\hline November & 20 & 27 & 22 & 25 & 20 & 25 & 20 & 25 & 19 & 25 & 22 & 25 & 22 & 37 \\
\hline December & 21 & 27 & 20 & 25 & 20 & 25 & 20 & 25 & 22 & 25 & 18 & 26 & 22 & 25 \\
\hline
\end{tabular}


Table 3. Expansion of central core of Saudi Arabian high pressure.

\begin{tabular}{ccccccc}
\hline & min Oct & $\max$ Oct & $\min$ Nov & $\max$ Nov & $\min$ Dec & $\max$ Dec \\
\hline $1948-58$ & 24 & 30 & 20 & 27 & 21 & 27 \\
$1958-68$ & 22 & 27 & 22 & 25 & 20 & 25 \\
$1968-78$ & 24 & 27 & 20 & 25 & 20 & 25 \\
$1978-88$ & 22 & 27 & 20 & 25 & 20 & 25 \\
$1988-98$ & 24 & 29 & 19 & 25 & 22 & 25 \\
$1998-2008$ & 24 & 30 & 22 & 25 & 18 & 26 \\
$2008-2014$ & 25 & 29 & 22 & 27 & 22 & 25 \\
\hline
\end{tabular}

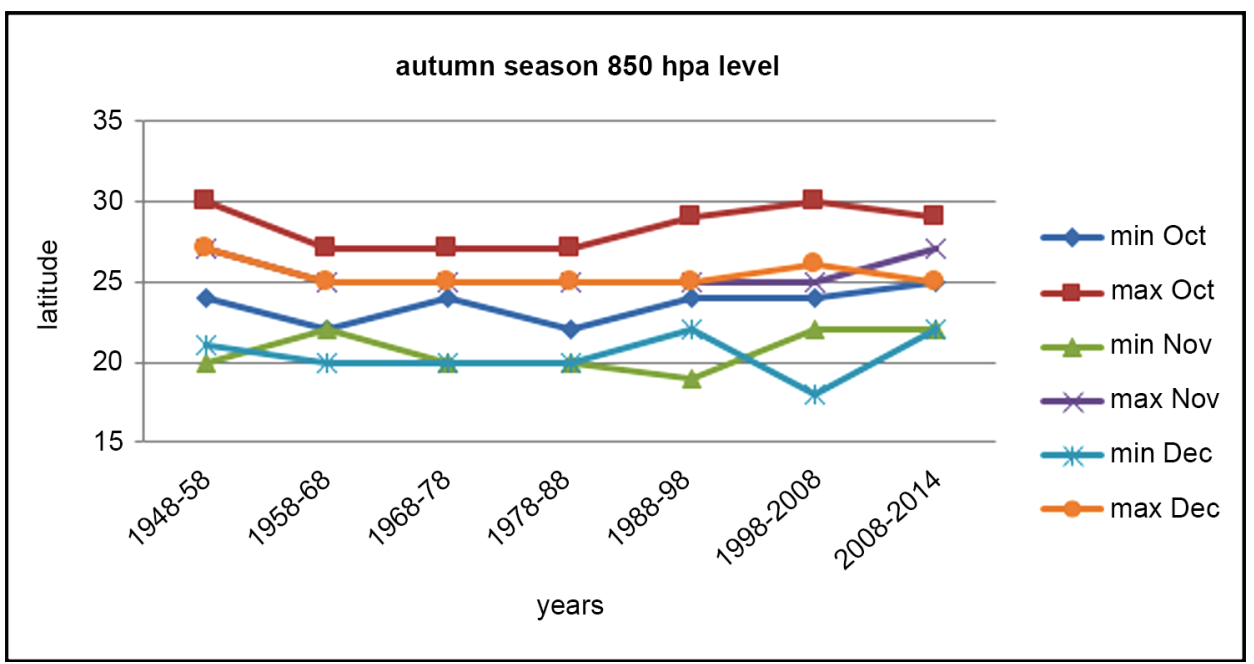

Diagram 1. Changes in high pressure core over 10-year time span in autumn.

decades $(1968-78 ; 1978-88 ; 1988-98)$, the lower limit oscillated between $19^{\circ}$ to $20^{\circ}$ north, but in the last two decades increased it $2^{\circ}$ again to $22^{\circ}$ north. This incoherency in the last decade (post-2008) was greater than in other decades and the centers expanded to $22^{\circ}$ to $27^{\circ}$ north latitude. In other words, the core of the high pressure centers was higher than in the other decades. In December, the core movement showed no special changes compared to November. In many decades, the centers were similar to those for November. Those for (1968-78) and (1978-88) were the same as their counterparts in November.

\subsubsection{Winter}

Table 4 shows the expansion of the central core of the high pressure in winter. In January at the beginning of the first decade, changes in the core were not significant (Diagram 2). The core remained $20^{\circ}-25^{\circ}$ north latitude; in the following decades, the centers relocated toward the lower latitudes and the center relocated $1^{\circ}-3^{\circ}$ in latitude toward the equator. The difference between the maximum expansions of points was greater than for the minimum expansion and relocated to $2^{\circ}-4^{\circ}$ in latitude. In this 
Table 4. Expansion of central core of high pressure in winter.

\begin{tabular}{ccccccc}
\hline & min Jan & $\max J a n$ & $\min$ Feb & $\max$ Feb & $\min$ Mar & $\max$ Mar \\
\hline $1948-58$ & 20 & 25 & 20 & 27 & 17 & 25 \\
$1958-68$ & 17 & 25 & 15 & 25 & 8 & 25 \\
$1968-78$ & 17 & 22 & 18 & 25 & 15 & 25 \\
$1978-88$ & 19 & 23 & 18 & 24 & 15 & 25 \\
$1988-98$ & 18 & 23 & 17 & 24 & 15 & 23 \\
$1998-2008$ & 19 & 22 & 17 & 23 & 18 & 23 \\
$2008-2014$ & 20 & 23 & 17 & 23 & 20 & 25 \\
\hline
\end{tabular}

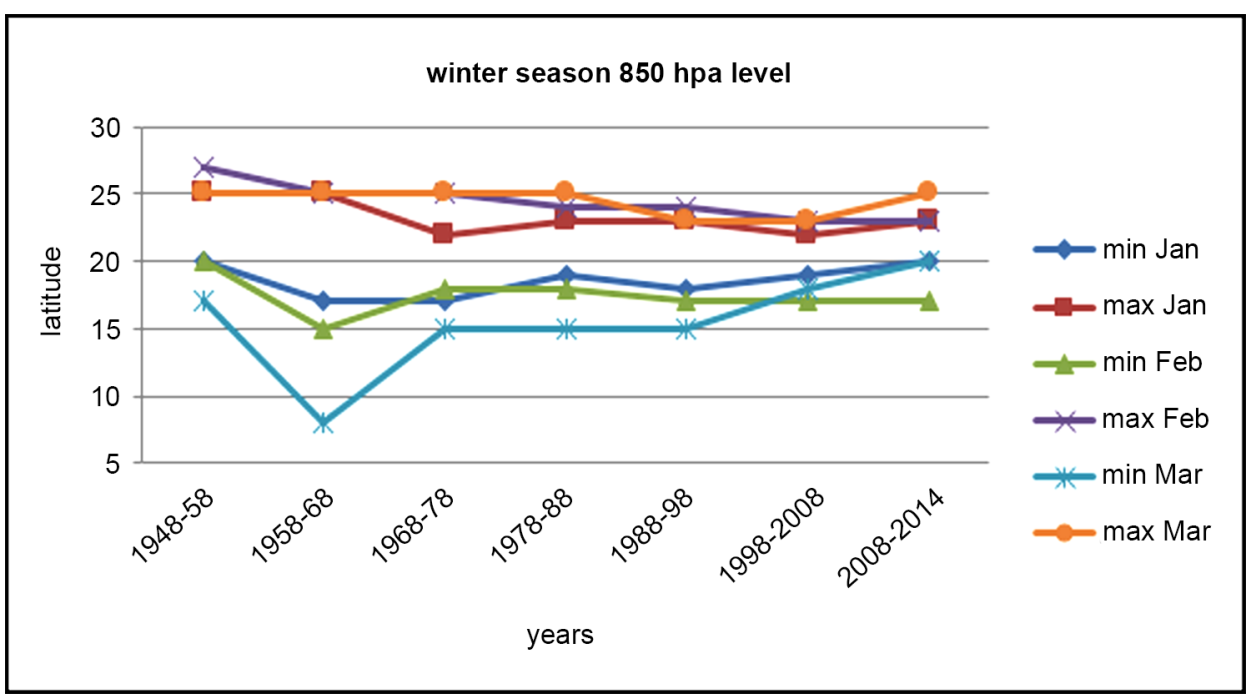

Diagram 2. Changes in central core of 3-month high pressure over 10-year time span in winter.

month, as in other months, the changes were smaller than for other decades and the cores were at $20^{\circ}-23^{\circ}$ north latitude.

In February, the central cores of the high pressure relocated toward the lower latitudes. In the first decade, these changes were not obvious, but changes in the following decades to the lower latitudes to the south were evident. The greatest relocation occurred for the lower limit of the center in 1958-68, which expanded to $23^{\circ}-25^{\circ}$ north latitude. In March, the cores relocated southward, especially for the lower limit of the center, which moved $2^{\circ}-3^{\circ}$ south. In the first decade (1948-58), this month, unlike other months, did not relocate southward. In the second to fifth decades, the lower limit of the centers was at $23^{\circ}-25^{\circ}$ north latitude. From 1988-98, the cores began to move northward, but this relocation was greater at the lower boundary of the cores. As seen, the southward movement of the centers ceased after January and the high pressure centers were transmitted to higher latitudes in accordance with the outward movement of the sun. Relocation of the general circulation systems did not occur and the Saudi Arabian high pressure continued to move southward. 


\subsubsection{Spring}

In Table 5, in April during most of the first four decades, the lower limit of core expansion moved $1^{\circ}-2^{\circ}$ northward, meaning that they moved toward Iran. In Diagram 3 , in 1988-98, this reversal toward the north was more impressive at up to $4^{\circ}$. In the last decade, however, the lower limit of expansion has remained southward. The higher limit of expansion moved southward in all of decades to $21^{\circ}-24^{\circ}$ north latitude. This means that the centers turned toward Iran. The higher limit of the cores did not return the March conditions; they remained below $25^{\circ}$ in latitude at $19^{\circ}-24^{\circ}$ north.

In June, impressive upward movement was seen for all decades. The lower limit of expansion of the high pressure cores was above $41^{\circ}$ north latitude, except in 1958-68 and 1978-88. In these two decades, the core was positioned above $34^{\circ}$ north latitude. This meant that the lower limit of expansion of the high pressure core moved $15^{\circ}$ in comparison with the previous month of May. In other decades, it moved primarily $22^{\circ}$ north. This demonstrates that reversal of the Saudi Arabian high pressure core reversal toward north began in April. It is interesting to note the intense northward movement in June, which is the turning point for relocation of the high pressure core northward. Real summer in Iran starts in June [17].

Table 5. Expansion of central core of high pressure.

\begin{tabular}{ccccccc}
\hline & min Apr & max Apr & min May & max May & $\min$ Jun & max Jun \\
\hline $1948-58$ & 18 & 23 & 19 & 24 & 43 & 51 \\
$1958-68$ & 16 & 24 & 21 & 24 & 38 & 45 \\
$1968-78$ & 16 & 21 & 19 & 23 & 41 & 45 \\
$1978-88$ & 17 & 22 & 19 & 24 & 34 & 45 \\
$1988-98$ & 19 & 21 & 19 & 24 & 43 & 51 \\
$1998-2008$ & 17 & 22 & 20 & 24 & 44 & 47 \\
$2008-2014$ & 15 & 23 & 19 & 23 & 42 & 48 \\
\hline
\end{tabular}

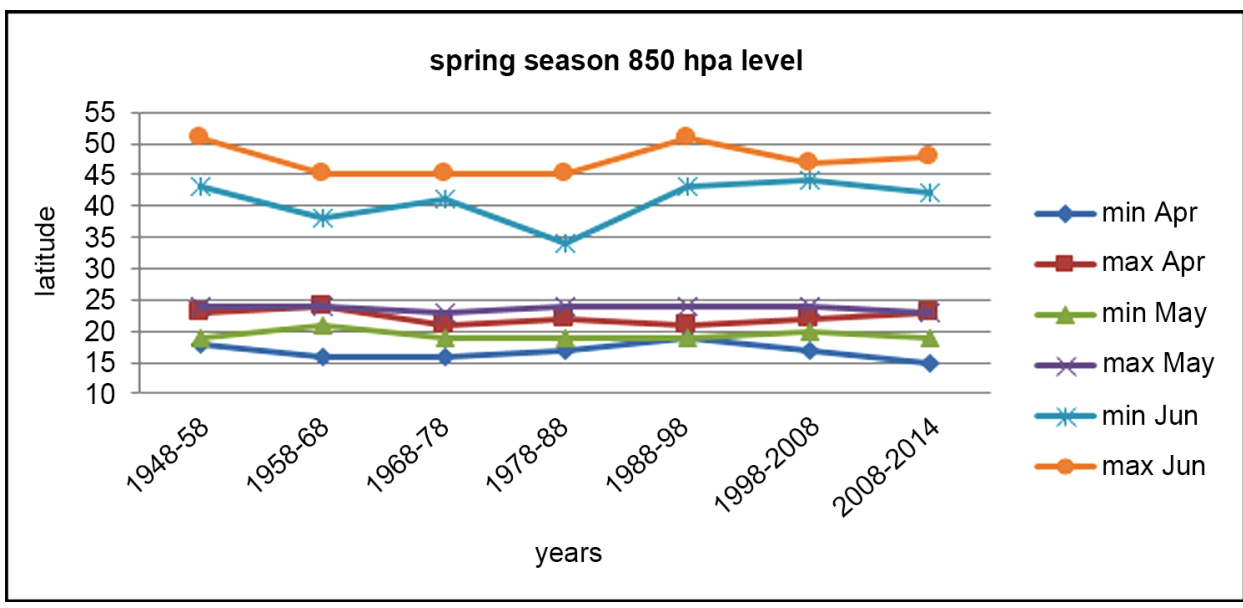

Diagram 3. Changes in central core of 3-month high pressure over 10-year time span in spring. 


\subsubsection{Summer}

During the three months of summer, northward relocation was trivial. In most of the six decades, the high pressure cores oscillated between $37^{\circ}-52^{\circ}$ north latitude. Overall, there was no significant oscillation of the core during the summer [11].

\subsection{Changes in Saudi Arabian Longitudinal High Pressure}

Table 6 shows the longitudinal changes in the Saudi Arabian subtropical high pressure the last six decades by season. Studies show that eastward movement of Saudi Arabian high pressure and its position over the hot and humid Sea of Oman and Arabian Sea, especially in the lower levels, increased rainfall in Iran. The westward movement of the high pressure zone decreased rainfall in Iran because it prevented the Sudanese low pressure and the Mediterranean hod from dispersing into the lower latitudes [11].

\subsubsection{Autumn}

Diagram 4 shows the longitudinal changes in the Saudi Arabian subtropical high pressure in the autumn. It was expected that in October, being the first month after autumnal temperance, that the Saudi Arabian subtropical high pressure would exit Iran and

Table 6. Longitudinal changes in Saudi Arabian subtropical high pressure over six decades.

\begin{tabular}{ccccccc}
\hline & min Oct & $\max$ Oct & $\min$ Nov & $\max$ Nov & $\min$ Dec & $\max$ Dec \\
\hline $1948-58$ & 46 & 50 & 50 & 55 & 49 & 52 \\
$1958-68$ & 44 & 50 & 48 & 58 & 48 & 52 \\
$1968-78$ & 44 & 51 & 49 & 53 & 46 & 52 \\
$1978-88$ & 43 & 51 & 48 & 56 & 48 & 55 \\
$1988-98$ & 45 & 51 & 48 & 55 & 48 & 60 \\
$1998-2008$ & 42 & 51 & 50 & 58 & 46 & 68 \\
$2008-2014$ & 44 & 48 & 55 & 55 & 52 & 52 \\
\hline
\end{tabular}

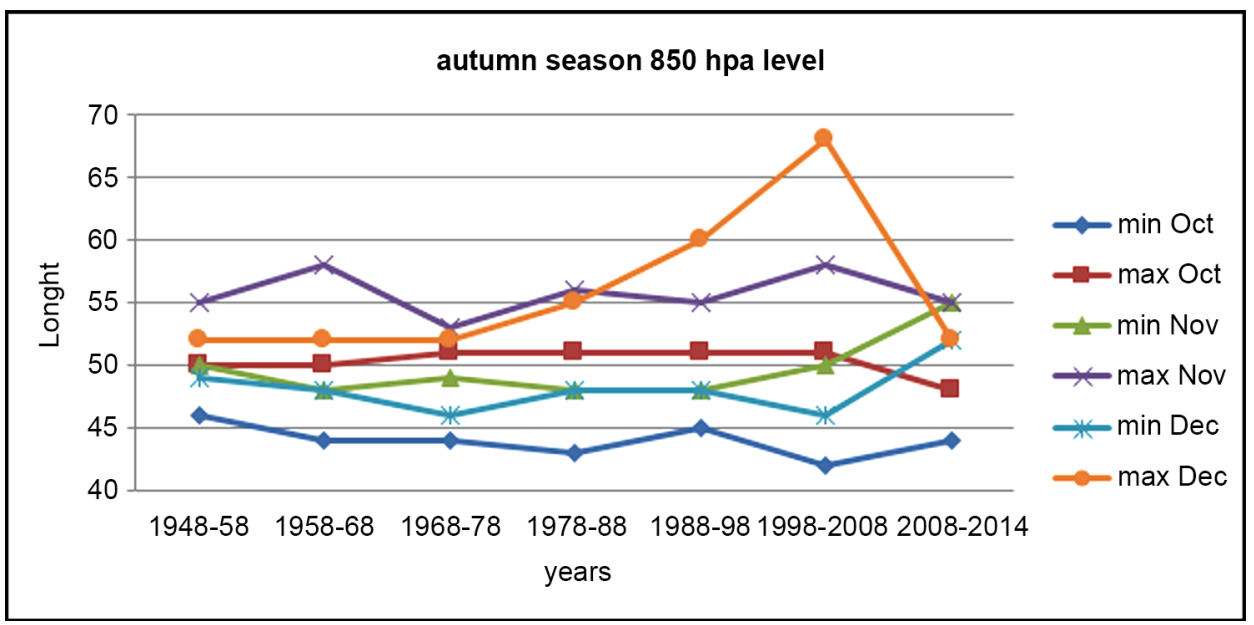

Diagram 4. Longitudinal changes in Saudi Arabian subtropical high pressure in autumn. 
move southward to the lower latitudes allowing entry of rainfall systems. In this month, the central core of high pressure oscillated between $42^{\circ}-51^{\circ}$ east longitude. The eastern boundary oscillated between $50^{\circ}$ and $51^{\circ}$, but the western boundary showed greater oscillation and moved between $42^{\circ}-46^{\circ}$ east longitude. In 1958-68, the cores moved significantly eastward and in 2008-14 it showed a significant westward relocation.

In November, the high pressure core dispersed significantly eastward in all decades. The western limit of core dispersion was $45^{\circ}-50^{\circ}$ east longitude and the eastern limit of dispersion was $53^{\circ}-58^{\circ}$ east longitude. On average, the core moved westward $5^{\circ}$ in comparison with the previous month. In November, the western-most position of the core occurred in the first decade (1948-58); the other decades were similar and change was not significant. In December, the changes were also not significant. In some years the movement was $1^{\circ}-2^{\circ}$ westward and sometimes eastward. On average, the central core of high pressure was location at $48^{\circ}-55^{\circ}$ east longitude. The most dispersion was observed in 1998-2008.

\subsubsection{Winter}

Table 7 and Diagram 5 show the expansion of the central core of high pressure in

Table 7. Longitudinal changes in Saudi Arabian subtropical high pressure in winter.

\begin{tabular}{ccccccc}
\hline & min Jan & max Jan & min Feb & $\max$ Feb & $\min$ Mar & $\max$ Mar \\
\hline $1948-58$ & 48 & 55 & 50 & 60 & 55 & 62 \\
$1958-68$ & 48 & 53 & 50 & 60 & 51 & 58 \\
$1968-78$ & 48 & 52 & 50 & 60 & 52 & 62 \\
$1978-88$ & 48 & 54 & 50 & 60 & 53 & 58 \\
$1988-98$ & 48 & 55 & 52 & 60 & 50 & 60 \\
$1998-2008$ & 50 & 58 & 50 & 60 & 52 & 59 \\
$2008-2014$ & 50 & 56 & 52 & 55 & 50 & 60 \\
\hline
\end{tabular}

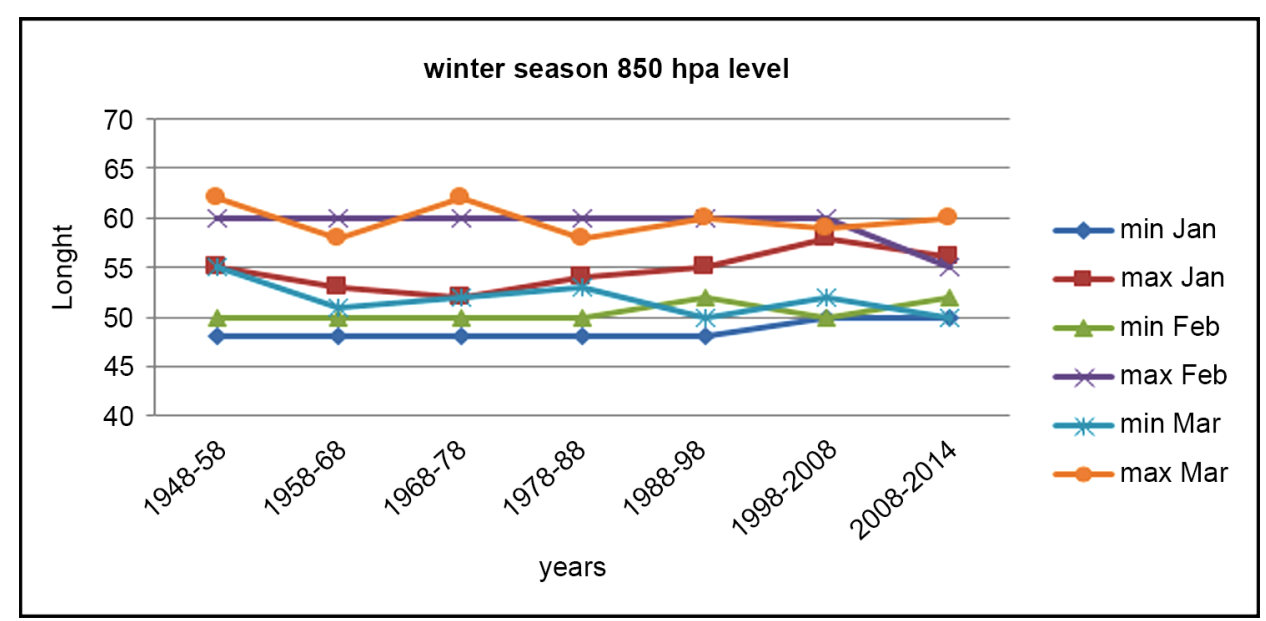

Diagram 5. Longitudinal changes in Saudi Arabian subtropical high pressure in winter. 
winter. In January and February, the movement of the core was more orderly. The central core was positioned at $48^{\circ}$ to $55^{\circ}$ east longitude in January. In the last decade, the core has moved toward the east. The order is more obvious in February and, except for the most recent decades, the central core was positioned at $50^{\circ}$ to $60^{\circ}$ in longitude. In March, the movement of the central core became slightly disordered. In general, the center was positioned between $50^{\circ}$ to $60^{\circ}$ east longitude, which is a difference of $2^{\circ}$ eastward from February.

\subsubsection{Spring}

Table 8 and Diagram 6 show the longitudinal movement of the central core in spring. April is the first temperate month and the high pressure core moved slightly to the west. In general, the location of high pressure core was sporadic at between $52^{\circ}$ to $62^{\circ}$ east longitude. In comparison with the winter months, it showed no intense eastward or westward movement. Impressive westward movement was observed in May; in most decades, the center was positioned between $44^{\circ}-48^{\circ}$ up to $50^{\circ}$ east longitude. In other words, the core moves strongly northward $10^{\circ}$.

Table 8. Longitudinal changes in Saudi Arabian subtropical high pressure in spring.

\begin{tabular}{ccccccc}
\hline & min Apr & max Apr & min May & max May & $\min$ Jun & max Jun \\
\hline $1948-58$ & 53 & 60 & 44 & 47 & 45 & 57 \\
$1958-68$ & 51 & 59 & 36 & 51 & 50 & 55 \\
$1968-78$ & 54 & 60 & 46 & 49 & 40 & 58 \\
$1978-88$ & 53 & 58 & 46 & 51 & 54 & 58 \\
$1988-98$ & 53 & 57 & 44 & 51 & 55 & 63 \\
$1998-2008$ & 51 & 59 & 45 & 48 & 49 & 53 \\
$2008-2014$ & 50 & 62 & 45 & 47 & 49 & 55 \\
\hline
\end{tabular}

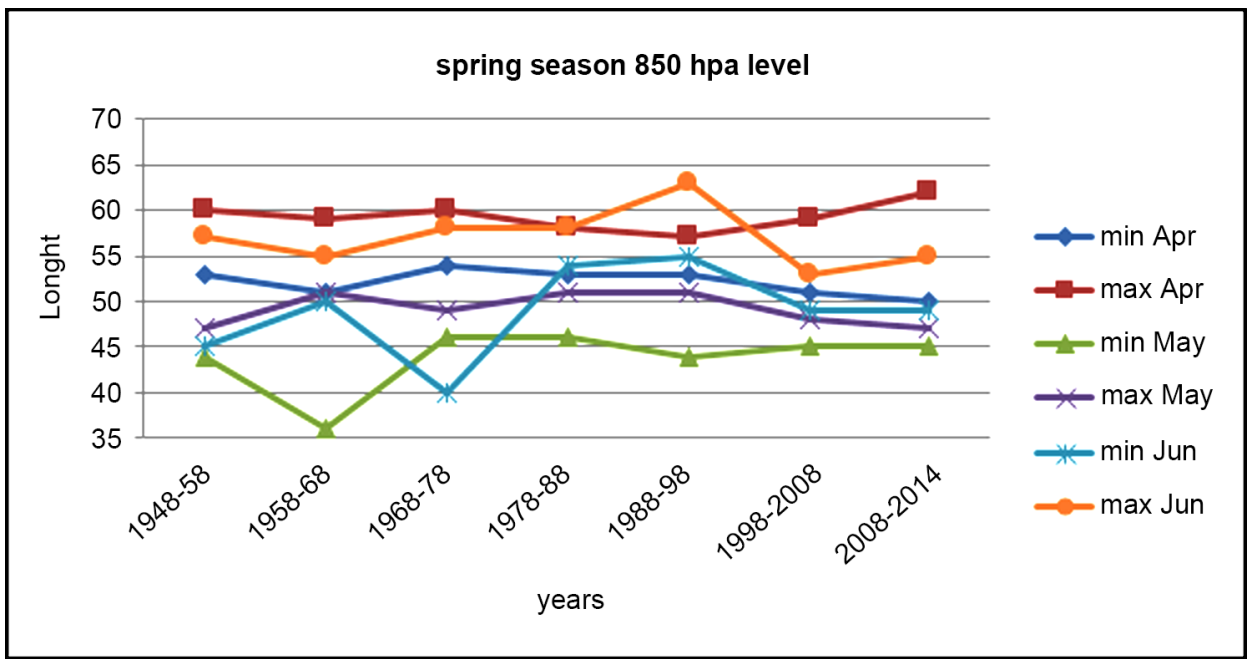

Diagram 6. Longitudinal changes in Saudi Arabian subtropical high pressure in spring. 


\subsubsection{Summer}

Table 9 and Diagram 7 show the longitudinal changes in the central core of the Saudi Arabian subtropical high pressure in summer over the course of 66 years. July is the beginning month of summer in the northern hemisphere. The core of the high pressure was positioned at $50^{\circ}$ to $56^{\circ}$ east longitude in first three decades (1948-78). In 1978-88, the core moved slightly eastward to a position at $54^{\circ}$ to $66^{\circ}$ east longitude. It returned to the previous condition in the next decade (1988-98). It is interesting to note the impressive movement of the high pressure core westward in 1998-2008. In this decade, the core was positioned at $41^{\circ}$ to $53^{\circ}$ east longitude and the western boundaries moved significantly westward. This phenomenon has also occurred in the last decade. In August, the core was more orderly and the central core expanded to between $50^{\circ}$ and $60^{\circ}$ longitude with little oscillation. In September 1968-98, the western boundary of the core moved eastward east $3^{\circ}$ to $4^{\circ}$.The core of the Saudi Arabian high pressure in the lower levels (below $850 \mathrm{HPa}$ ), especially when all or part of the high pressure area was positioned over the warm Arabian Sea and Sea of Oman, moved humidity into the Arabian

Table 9. Longitudinal changes in Saudi Arabian subtropical high pressure in summer.

\begin{tabular}{ccccccc}
\hline & min Jul & max Jul & min Age & max Age & $\min$ Sep & max Sep \\
\hline $1948-58$ & 50 & 54 & 50 & 55 & 52 & 55 \\
$1958-68$ & 51 & 54 & 52 & 55 & 54 & 60 \\
$1968-78$ & 50 & 56 & 53 & 58 & 56 & 57 \\
$1978-88$ & 54 & 60 & 53 & 60 & 56 & 59 \\
$1988-98$ & 51 & 59 & 54 & 57 & 55 & 61 \\
$1998-2008$ & 41 & 53 & 52 & 54 & 50 & 54 \\
$2008-2014$ & 48 & 51 & 50 & 53 & 53 & 54 \\
\hline
\end{tabular}

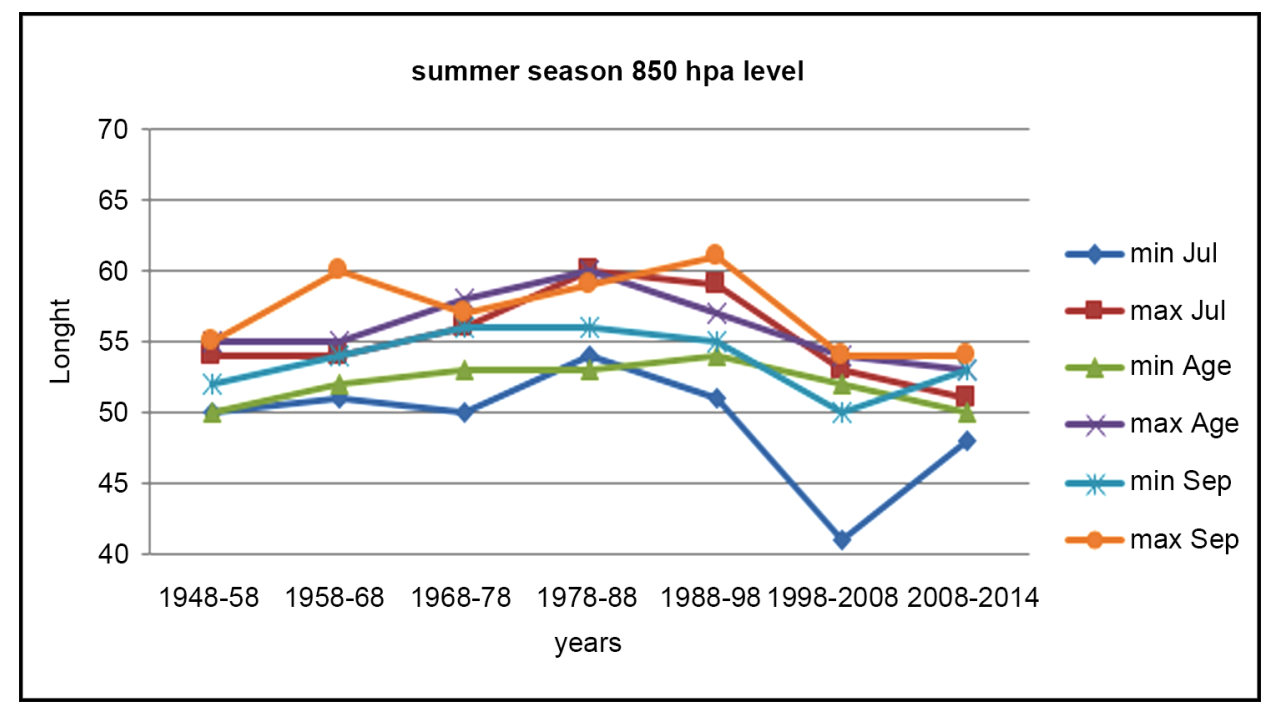

Diagram 7. Longitudinal changes in Saudi Arabian subtropical high pressure in summer. 
Peninsula and Iran. If this condition were accompanied by unstable swings in the higher layers, it caused intense convection rainfall in the area. If the atmosphere was stable in the higher layers, sultry conditions increased in the area, especially in summer.

\section{Conclusions}

High pressure over Saudi Arabia is the determinative factor for weather in the Middle East. Its annual relocation defines daily atmospheric conditions in the area. Its eastward movement increases rainfall in Iran, Saudi Arabia and Iraq, and its westward movement causes stability in most west Asian countries (Figure 3).

Westward movement of the Saudi Arabian high pressure causes expansion of western winds and brings about penetration of rain systems. Movement northward causes intense stability in the area and decreases western winds. This study of the central core of the system at sea level 700, and $850 \mathrm{HPa}$ over the course of 66 years shows that:

1) The central core of this system lies between $22^{\circ}-30^{\circ}$ north latitude and $42^{\circ}-50^{\circ}$ east longitude (northern Saudi Arabia). Image (3) shows an example of core dispersion in October.

2) The westward relocation of the high pressure core continues until the end of March; in this month, the core lies at $15^{\circ}$ to $25^{\circ}$ north latitude and $50^{\circ}$ to $66^{\circ}$ east longitude. This means that it is incorrect to expect southward movement of the high pressure center to continue to January and that with outward movement from the sun, the center will move toward north to higher layers.

3) The Saudi Arabian high pressure reversal northward begins with the onset of April

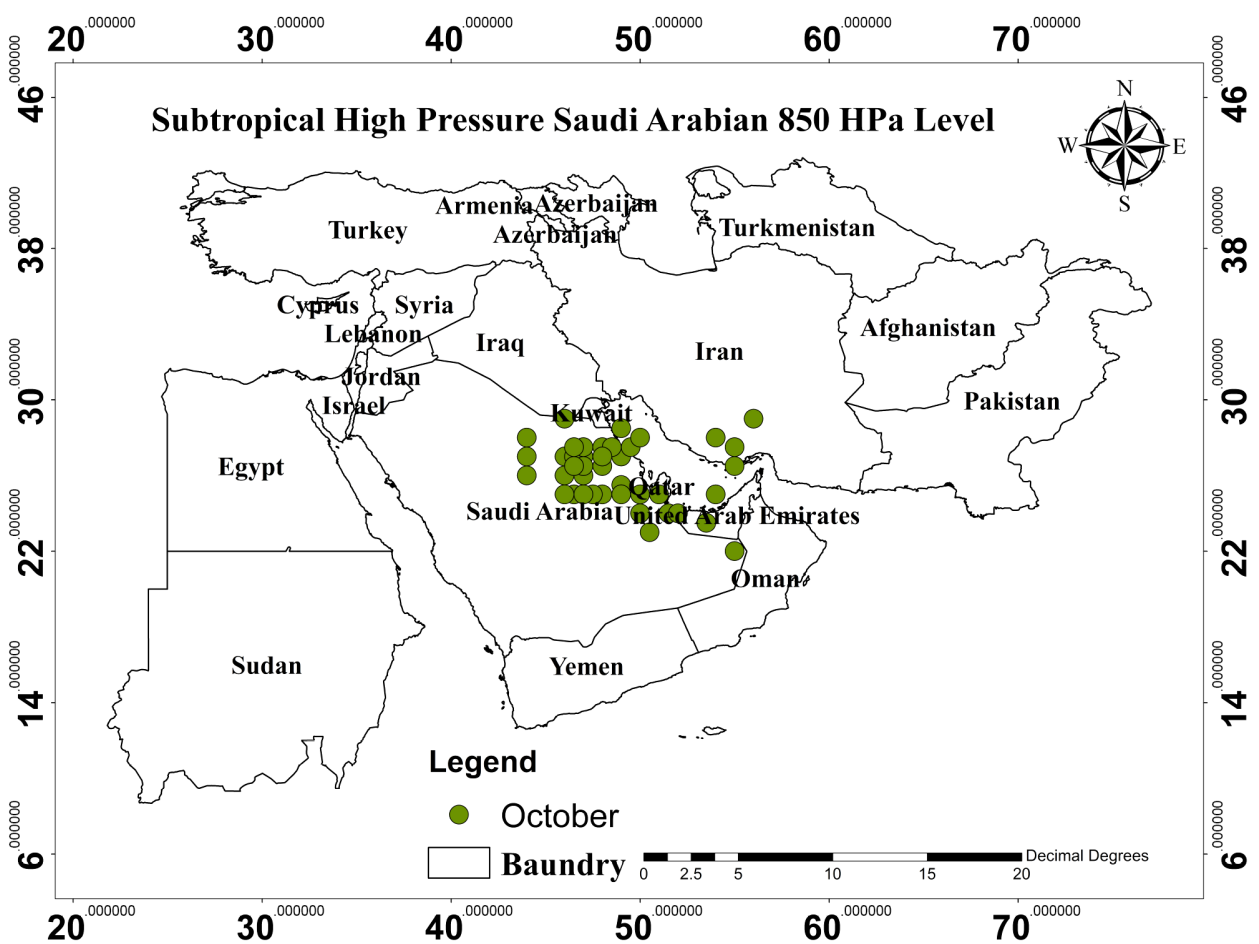

Figure 3. Dispersion of central core of Saudi Arabian subtropical high pressure. 
and by June this reversal is impressive and unexpected. The density of the core in June is between $34^{\circ}$ to $51^{\circ}$ north latitude and $45^{\circ}$ to $58^{\circ}$ east longitude. In other words, the core moves suddenly $20^{\circ}-30^{\circ}$ northward. June is the turning point for seasonal change and rapid transformation of the high pressure centers to higher latitudes.

The second rapid relocation occurs in October. The relocation of the central core in September and October occurs suddenly and October is the second turning point for the Saudi Arabian subtropical high pressure (Figure 3).

\section{References}

[1] Hassan, L. (2002) Routing Low Pressure Systems to Iran. Tarbiat Modares University, Tehran, 41.

[2] Hooshang, G., Azar, Z., Majed, A. and Manocher, F. (2009) Analyzing the Patterns of Subtropical High Pressure over Asia and Africa. Journal of Humanities, 219-245.

[3] Abrahim, J. (2009) Book Cimatology. University of Tehran Press, Tehran.

[4] Hoskins, B. (1996) On the Existence and Strength of the Summer Subtropical Anticyclones. Bernhard Haurwitz Memorial Lecture. Bulletin of the American Meteorological Society, 77, 1287-1292.

[5] Saligheh, M. (2007) The Precipitation Mechanism in the South East of the Country. Geographical Journal, 1-13.

[6] Saligheh, M. and Sadeghinia, M. (2007) Spatial Variation of Summer Precipitation in the Southern Half of the Subtropical High Pressure Iran. Journal of Geography and Development, 83-98.

[7] Hejazizadeh, Z. (1993) Evaluation of a Subtropical High-Pressure Synoptic Weather in Iran. PhD Thesis, Tarbiat Modares University, Tehran.

[8] Hassan, L. (2011) Book Fundamentals of Preparing Interpret Maps and Climate Charts. University of Beheshti Press, Tehran, 189-192.

[9] Kianpour, M. (2000) Synoptic Survey El Nino Phenomenon and Its Relation to Rainfall Anomalies in Southern and Southwestern Iran. M.Sc. Thesis, Tarbiat Modares University, Tehran.

[10] He, X.-Z. and Gong, D.-Y. (2002) Inter Decadal Change in Western Pacific Subtropical High and Climatic Effects. Journal of Geographical Sciences, 12, 202-209.

http://dx.doi.org/10.1007/BF02837475

[11] Hassan, L. and Zainb, M. (2015) The Role of Saudi Arabia High Pressure Subtropical Settlement Position on Precipitation Systems in the South and Southwest of Iran. Geographical Journal, vol., 73-90.

[12] Hasanean, H.M. (2004) Variability of the North Atlantic Subtropical High and Associations with the Tropical Sea Surface Temperature. International Journal of Climatology, 24, 945957. http://dx.doi.org/10.1002/joc.1042

[13] Azizi, Q. (1996) Heavy Rains in Southwestern Iran Synoptic Patterns. PhD Thesis, Tarbiat Modares University, Tehran.

[14] Sadeghi, S., Alijani, B., Saligheh, M., Habibi-Nokhandan, M. and Ghahroudi Talley, M. (2008) Synoptic Analysis Anticyclone over Widespread Drought in Khorasan. Journal of Geography and Regional Development, 105-118.

[15] Iqbal, M.J., Hameed, S. and Khan, F. (2013) Influence of Azores High Pressure on Middle Eastern Rainfall. Theoretical and Applied Climatology, 111, 211-221. 
http://dx.doi.org/10.1007/s00704-012-0648-4

[16] Ahmadi-Givi, Iran-Nejad, F. and Mohammad-Nejad, A. (2010) Impact of Subtropical High Pressure and Droughts, West Siberia, Iran. Fourteen of the Geophysics Conference of Iran, Tehran, 21-23 May, 5-9.

[17] Mu, Q., Wang, S., Cai, J., Xie, Z. and Zhu, J. (2002) Modelling Studies on the Changes of the Subtropical High over the Western Pacific during the Last 100 Years. Department of Atmospheric Science, College of Physics, Peking University, Beijing, 4 p.

Submit or recommend next manuscript to SCIRP and we will provide best service for you:

Accepting pre-submission inquiries through Email, Facebook, LinkedIn, Twitter, etc. A wide selection of journals (inclusive of 9 subjects, more than 200 journals)

Providing 24-hour high-quality service

User-friendly online submission system

Fair and swift peer-review system

Efficient typesetting and proofreading procedure

Display of the result of downloads and visits, as well as the number of cited articles

Maximum dissemination of your research work

Submit your manuscript at: http://papersubmission.scirp.org/ 